原 著

\title{
慢性期における右室流出路中隔ペーシングと 右室心尖部ペーシングの比較
}

清野正典* 田中数彦* 虎渓則孝* 中原志朗*

酒井良彦* 高柳 寛*

右室心尖部ペーシングの心機能に対する悪影響が大規模な研究により明らかにな り，その弊害を減らすために右室流出路中隔ペーシングの積極的な導入が検討され ている，しかし，短期の報告が多く慢性期の結果については不明であつたため，今 回の研究で慢性期の結果を比較検討した. 対象は心機能の低下のないペースメーカ 適応症例とした。各 20 症例を右室流出路中隔群と右室心尖部群とに分け, QRS 幅 の変化, 閾値, 感度, 抵抗値, BNP值, 左室駆出率, 新規の心房細動 (AF)の有無, $\mathrm{AF}$ 持続時間について 24 カ月にわたり観察, 検討した. 結果, 右室流出路中隔群の ほうがQRS 幅は狭く, BNP 值も低下した. ペースメーカのパラメータは両群に差は 認めなかつた，AFの発生率は右室流出路中隔群にて低い傾向があり，AFの持続時 間の平均は短かつた，右室流出路中隔ペーシングは右室心尖部ペーシングと同様に 管理は容易であり，心機能への影響も小さく，AFの悪化も少ないと考えられた.

(心電図, $2009 ； 29 ： 333 \sim 340$ )

I. 背

景

右室心尖部ペーシングは, 徐脈性不整脈に対して 確立した治療法とされてきた。しかし近年，右室心 尖部ペーシングによる心機能の低下，心房細動 $(\mathrm{AF})$ などの不整脈に対する悪影響が大規模な研究により

\begin{tabular}{|c|c|}
\hline Keywords & $\begin{array}{l}\text {-右室流出路中隔ペーシング } \\
\text {-心房細動 }\end{array}$ \\
\hline
\end{tabular}

$*$ 獨協医科大学越谷病院

（† 343-8555 埼玉県越谷市南越谷2-1-50)
明らかとなってきた ${ }^{1) 8)}$.

さらに，右室心尖部ペーシングは左室壁運動異常 を引き起こし，その結果左心機能を低下させ，僧帽 弁逆流の悪化，AFなどの不整脈を発生させやすく するなどの研究結果が相次いで報告された ${ }^{9211)}$.

右室心尖部ペーシング以外の様々な工夫が検討さ れ, その一つとして右室流出路中隔ペーシングが試

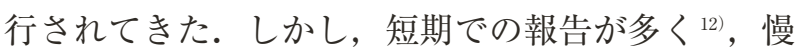
性期の結果についてはいまだ不明であることから， 本研究では慢性期での比較検討を行った。また，右

Compartion of the right ventricular outflow tract pacing with the right ventricular apex pacing in the chronic phase Masanori Seino, Kazuhiko Tanaka, Noritaka Toratani, Shiro Nakahara, Yoshihiko Sakai, Kan Takayanagi 
室流出路中隔ペーシングと $\mathrm{AF}$ の因果関係も報告が 少ないため，これについても検討した。

\section{II. 方法}

ペースメーカ適応となった心機能低下のない $(\mathrm{EF}>40 \%)$ 症例を対象に，右室流出路中隔群 (RVOT 群) と右室心尖部群 (RVA 群)に分け，それ ぞれ 20 症例ずつ前向きに検討した。本研究は当施設 の倫理検討委員会の承諾を受けたうえで，対象者に はペーシング部位の説明をし，文書にて同意を得た.

RVOT群には発作性 AF例が4例，RVA群では慢 性 $\mathrm{AF}$ 例が 3 例，発作性 $\mathrm{AF}$ 例が3例含まれていた。

それぞれの群の観察期間は 24 カとし, 観察項目 はQRS幅，右室ペーシング閾值，右室波感度，右室 リード抵抗值，BNP 值，左室駆出率 $(\mathrm{EF})$, 左室拡 張期径/収縮期径 (LVDd/Ds)，左房径 (LA)，心室 中隔と左室後壁の最大移動点の時間差 (Septal to posterior wall motion delay; SPWMD), 新規の AF の有無， $\mathrm{AF}$ 持続時間についてそれぞれ比較検討し た。術前のQRS幅, SPWMD は洞不全症候群のよう に伝導がある場合と，房室ブロックのように伝導が なく接合部調律または一時的ペーシングされている 場合とでは，条件が著しく異なるため今回は観察項 目としなかった。

右室流出路中隔群のリードの位置については,リー ドを右室流出路の高さで, かつ透視にて左前斜位 45 度 でリード先端を中隔に向けながらスクリューインを 用いて固定した。本研究では，右室流出路中隔に リード留置困難な症例は認めなかった。

新規の発作性 $\mathrm{AF}$ の有無については, (1)ホルター 心電図，12誘導心電図にて記録されている場合，(2) ペースメーカの記録より心房のHigh rate episode (A-A 間隔 175/分) の検出が 30 秒以上続いた場合を 有とした。 $\mathrm{AF}$ 持続時間はペースメーカの記録より 検証し，( $\mathrm{AF}$ 持続時間/観察時間 $) \times 100 \%$ によ示 した。

\section{III. 統計学的検討}

各観察項目はANOVA で検定し，その後TurkeyKramer 法にて多重比較を行い, $\mathrm{p}<0.05$ を統計学的 に有意とした。数值は平均值土標準偏差で表示した.

$\mathrm{AF}$ の新規発生率については Kaplan-Meier 法にて 算出し, $\log$-rank検定を行った。

\section{IV. 結 果}

患者背景 (表 1)については, 性別, 年齢 (RVOT 群：71 \pm 9 y.o，RVA群： $68 \pm 7$ y.o ; ns)に両群間 で差を認めなかった。各群における内服薬について も両群間に差は認めなかった（表2).

また，本研究では洞不全症候群例でも $\mathrm{AF}$ の発生 を認めたため，心室ペーシング率が低くても対象と したが，両群間では心室ペーシング率に差を認めな かった（RVOT群： $71 \pm 34 \%$, RVA群 : $66 \pm$ $44 \%$; ns).

術前の左室駆出率 $(\mathrm{RVOT}$ 群 : $70 \pm 10 \%, \mathrm{RVA}$ 群： $64 \pm 11 \%$; ns), 左心室拡張期径 (RVOT群 : $51 \pm 10 \mathrm{~mm}$, RVA群： $53 \pm 11 \mathrm{~mm}$; ns), 左室収 縮期径 (RVOT 群 : $30 \pm 9 \mathrm{~mm}, \mathrm{RVA}$ 群 : $35 \pm$ $11 \mathrm{~mm} ; \mathrm{ns})$, 左房径 (RVOT群 : $39 \pm 5 \mathrm{~mm}$,

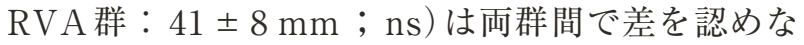
かった.

手術時間 (RVOT群 : $99 \pm 18 \mathrm{~min}, \mathrm{RVA}$ 群 : $120 \pm 54 \mathrm{~min} ; \mathrm{ns})$ も両群間で差を認めず，治療を 要するような合併症も認められなかった。

QRS幅は各群内で 24 カ月の観察期間中に有意な変 化を認めなかったが, 両群間の比較では全ての評価時 点においてRVOT群がRVA群より短かった（図1).

右室ペーシング閾值 (RVOT群 : $0.5 \pm 0.1 \mathrm{mv} /$ $0.4 \mathrm{msec}$, RVA群 : $0.7 \pm 0.3 \mathrm{mv} / 0.4 \mathrm{msec}$; ns), 右室波感度 $(R V O T$ 群：17 $\pm 8 \mathrm{mV}$, RVA群：13 $8 \mathrm{mV} ; \mathrm{ns}$ ), 右室リード抵抗值 (RVOT群：615 \pm 123 $\Omega, \mathrm{RVA}$ 群： $660 \pm 231 \Omega$ ；ns）は両群間に差はな く，経時的にも変化は認めなかった(図2).

24 カ月後のLA， EF，LVDd，LVDsは両群間で 
表1 患者背景

\begin{tabular}{|c|c|c|c|}
\hline & RVOT & RVA & $p$ \\
\hline Number of patients $(n)$ & 20 & 20 & ns \\
\hline Age (y.o.) & $71.0 \pm 9.1$ & $68.5 \pm 7.1$ & ns \\
\hline Gender (male/female) & $10 / 10$ & $7 / 13$ & ns \\
\hline Pacing mode $(\mathrm{n})$ & $\begin{array}{c}\text { DDD : } 19 \\
\text { VVI : } 1\end{array}$ & $\begin{array}{l}\text { DDD : } 6 \\
\text { VVI : } 7 \\
\text { VDD }: 7\end{array}$ & \\
\hline Indication for pacemaker implantation (n) & $\begin{array}{c}\text { C-AVB }: 10 \\
\text { Advanced AVB }: 4 \\
\text { SSS }: 6\end{array}$ & $\begin{array}{c}\text { C-AVB : } 7 \\
\text { Advanced AVB : } 4 \\
\text { SSS : } 6 \\
\text { Brady AF : } 3\end{array}$ & \\
\hline Pre EF (\%) & $70 \pm 10$ & $64 \pm 11$ & ns \\
\hline Pre LVDd (mm) & $51 \pm 10$ & $53 \pm 11$ & ns \\
\hline Pre LVDs $(\mathrm{mm})$ & $30 \pm 9$ & $35 \pm 11$ & ns \\
\hline Pre LA (mm) & $39 \pm 5$ & $41 \pm 8$ & ns \\
\hline Operation procedure time $(\mathrm{min})$ & $99 \pm 18$ & $120 \pm 54$ & ns \\
\hline \%Ventricular pacing & $71 \pm 34$ & $66 \pm 44$ & ns \\
\hline Major complications $(\mathrm{n})$ & 0 & 0 & \\
\hline Paroxysmal AF (+) (n) & 4 & 3 & \\
\hline Chronic AF (+) (n) & 0 & 3 & \\
\hline
\end{tabular}

各項目とも両群に差は認めなかった.

RVOT：右室流出路中隔ペーシング群，RVA：右室心尖部ペーシング群， EF：左室 駆出率, LVDd：左室拡張期径, LVDs：左室収縮期径, LA：左房径, AF：心房細 動，C-AVB：完全房室ブロック，Advanced AVB：高度房室ブロック，SSS：洞不全 症候群, Brady AF : 徐脈性心房細動

\section{表2 内服薬}

\begin{tabular}{|c|c|c|c|}
\hline & & RVOT & RVA \\
\hline \multirow{7}{*}{ 使用薬剂 } & Ca拮抗薬/降圧薬 & 2 & 2 \\
\cline { 2 - 4 } & 利尿剂 & 6 & 9 \\
\cline { 2 - 4 } & ACE/ARB & 4 & 7 \\
\cline { 2 - 4 } & I群抗不整脈薬 & 3 & 3 \\
\cline { 2 - 4 } & II 群抗不整脈薬 & 0 & 3 \\
\cline { 2 - 4 } & II群抗不整脈薬 & 1 & 0 \\
\cline { 2 - 4 } & IV群抗不整脈薬 & 1 & 0 \\
\cline { 2 - 4 } & ジギタリス製剤 & 0 & 2 \\
\hline
\end{tabular}

基礎疾患に対し適切な治療として内服加療されていた が，両群間に内服薬の差は認めなかった。

RVOT：右室流出路中隔ペーシング群, RVA：右室心 尖部ペーシング群

差はなく, 経時的な変化も認められなかった(図3). 術前のBNP值は両群間に差はなかったが (RVOT
群：224 $\pm 196 \mathrm{pg} / \mathrm{ml}, \mathrm{RVA}$ 群：178 $\pm 232 \mathrm{pg} / \mathrm{ml}$ ； ns)，24 カ月後にはRVOT群にてBNP值が低下した のに対し，RVA群では有意な変化を認められなかっ

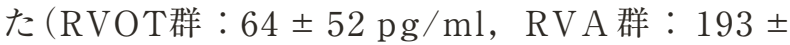
$189 \mathrm{pg} / \mathrm{ml}$ ) (図4).

SPWMDは 12 カ月時，両群間で差は認めなかった が，24 カ月後ではRVOT群で低下傾向を認め， RVA群との間に差が生じた(RVOT：71 $\pm 21 \mathrm{msec,}$ RVA : $147 \pm 37 \mathrm{msec}$ ) (図 5).

$\mathrm{AF}$ の新規発生については 24 力月間の観察で, RVOT群にて3例 (16例中；18\%)，RVA群にて7例 （14例中；50\%）とRVOT群のほうが発症率は低い傾 向を認めたものの，有意差は認められなかった(図6).

$\mathrm{AF}$ 持続時間はRVOT群では減少を認め (図7), 各群の持続時間の平均值を比べるとRVOT群で短 かった（17.8\% vs. $37.5 \% ； \mathrm{p}<0.05 ）($ 図7). 


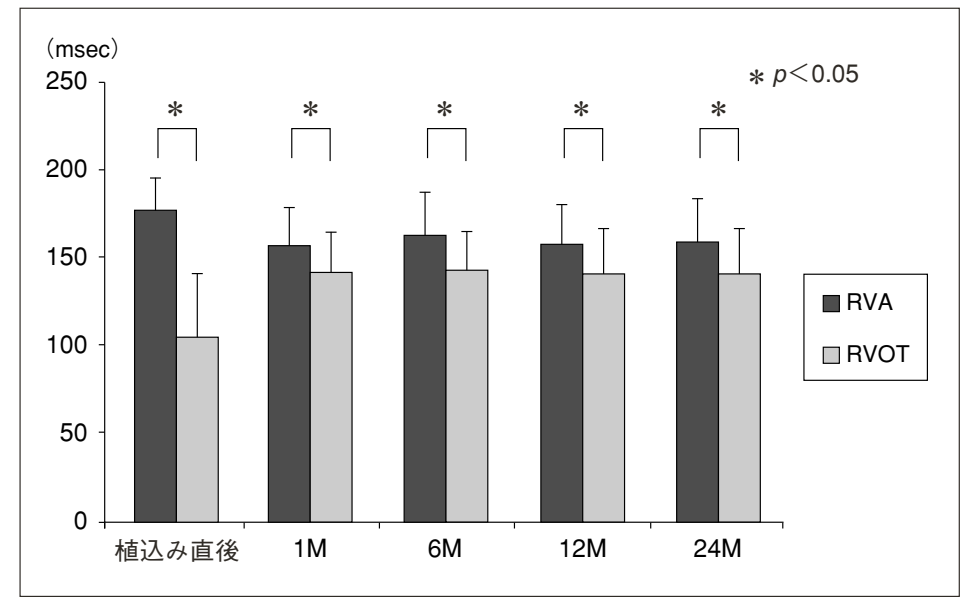

図 1

QRS幅の経時的比較

経時的にはRVOT群, RVA群ともにQRS幅の経時的変 化は認めないが，各時点での QRS幅はRVOT群のほう が短い.

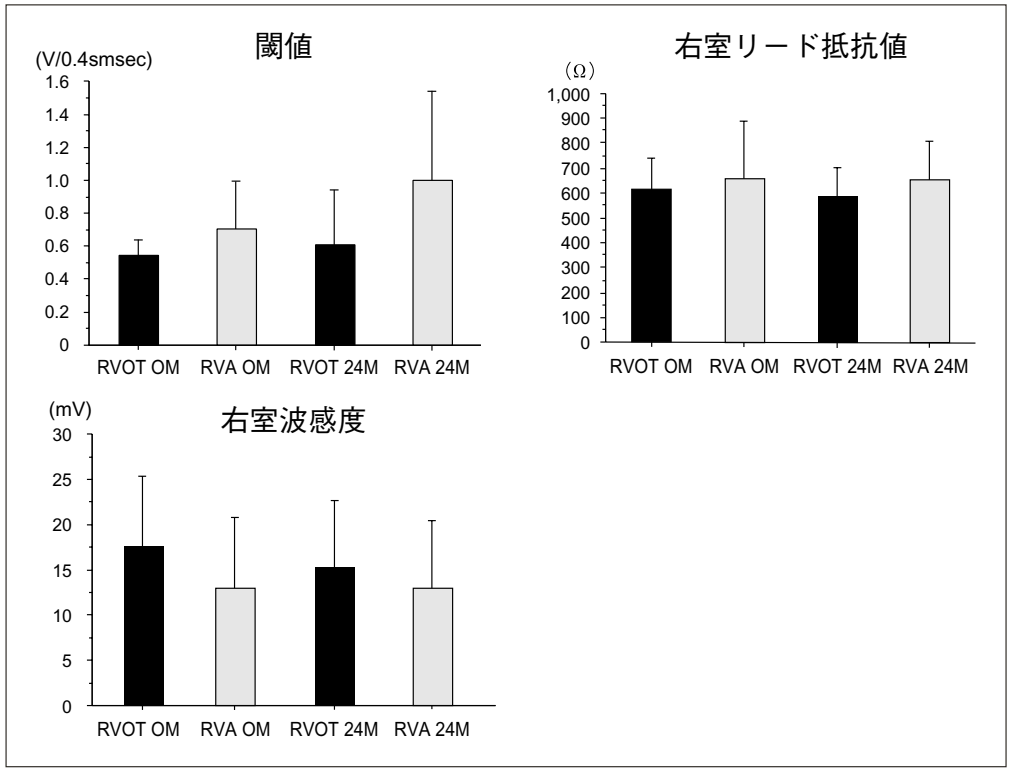

図2

右室ペーシング閾值・右室波感度・右室 リード抵抗值の経時的比較

いずれの項目も経時的に変化せず，安定した值で あった。

\section{V. 考察}

右室ペーシング閾值，右室波感度，右室リード抵 抗值より, 右室流出路中隔ペーシングは従来のペー シング位置である右室心尖部と同様にペースメーカ の管理は容易と思われる。手技的にも手術時間，合 併症の発生頻度より従来と同程度で, 安全性がある と考えられる。

右室心尖部ペーシングは非生理的な伝導をするた め，QRS幅の延長をきたし，その結果血行動態の低 下，左室のリモデリングを引き起こす。それゆえ， QRS幅が $160 \mathrm{msec}$ 以上の患者では心不全による入
院率が高くなると報告されている ${ }^{13)}$. また，その際 の QRS 幅が $10 \mathrm{msec}$ 延長するごとに心不全のリスク が17\%高まるとされている ${ }^{13)}$.

本研究でも RVA 群に比べてRVOT群ではペース メーカ植込み時より QRS幅は狭く，その結果として 非生理的な伝導の影響が少ないため，心不全のリス クを軽減できていると考えられる，RVOT群のBNP 值が24カ月時にRVA群に比べ低下していることも これを支持している.

同期不全の指標である SPWMD は 12 カ月時，両 群間で差がなかったのに対し 24 月では両群間に差 が生じた。これは上記と同様に非生理的な伝導によ JPN. J. ELECTROCARDIOLOGY Vol. 29 No. 52009 


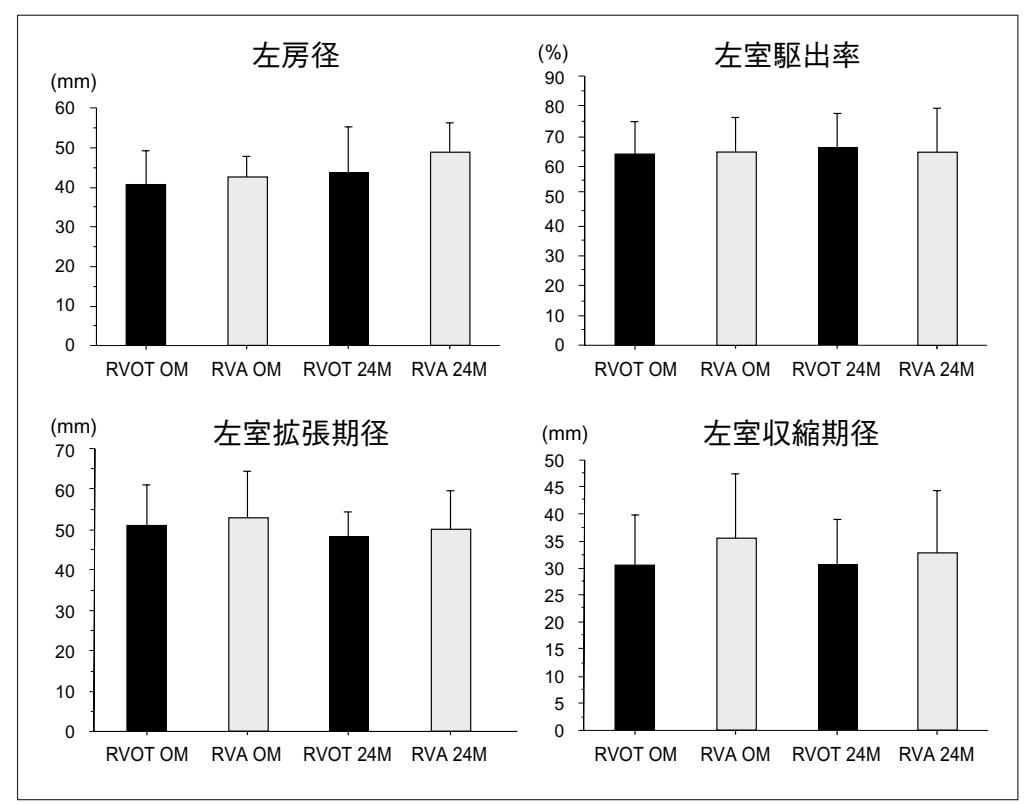

図3

左房径・左室駆出率・左室拡張期径・左室 短縮期径の経時的比較

心エコーにて比較したパラメー夕は差がなく，経 時的にみても変化は認められなかった。

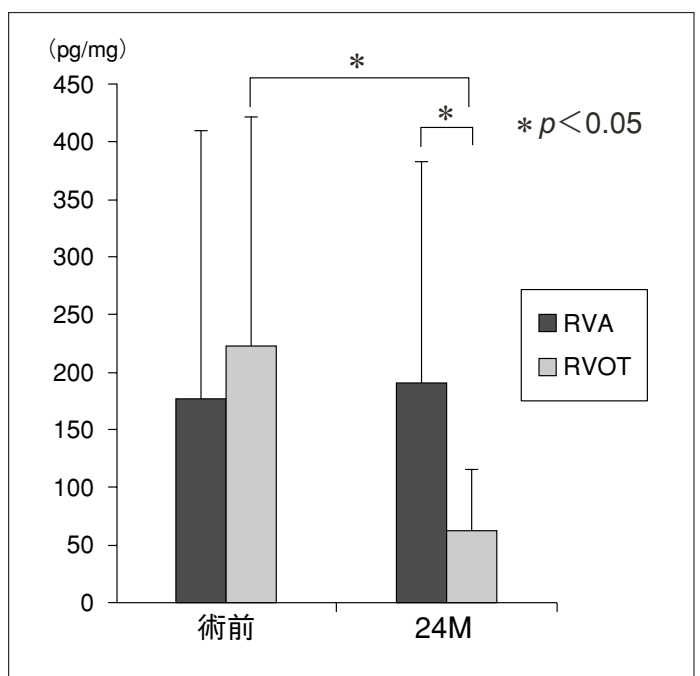

図4 BNP 值の経時的比較

BNP值はRVOT群では術前に比べ24カ月で減少していたが, RVA群では差を認めなかった。また，RVOT群のBNP值は 24 カ月時, RVA群より低かった。

る悪影響が少ないため，長期的に経過観察した際に， RVAペーシングに比べ同期不全をきたしにくいこ とによると考えられる。ただし術前のSPWMDは， 房室ブロックの場合や一時的ペーシングの影響で正 しく計測できないため，術前からの影響については 不明である。

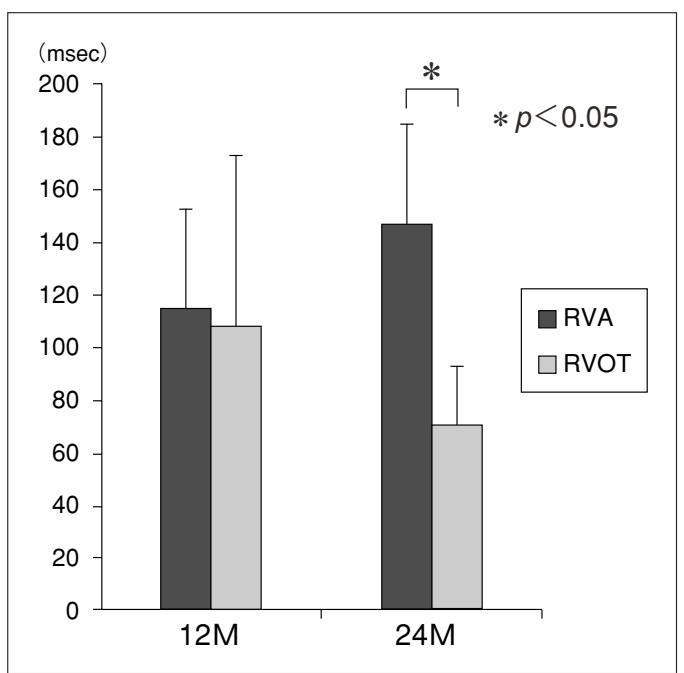

図5 心室中隔と左室後壁の最大移動点の時間差に おける経時的比較

12 力月時は両群間に差は認めなかったが，24 月月時はRVA 群はRVOT群と比べ延長している.

本研究において $\mathrm{AF}$ の新規発生率に差はなかった が，AF 持続時間はRVOT群にて低下した。ペーシ ングに関する大規模臨床研究の結果より，右室心尖 部ペーシングは $\mathrm{AF}$ の新規発生率，慢性 $\mathrm{AF}$ ○の移 行率を高めるとされた $\left.{ }^{1,}, 2\right), 6$, 10) 一方，右室流出路中 隔ペーシングは $\mathrm{AF}$ 悪化させなかった。 

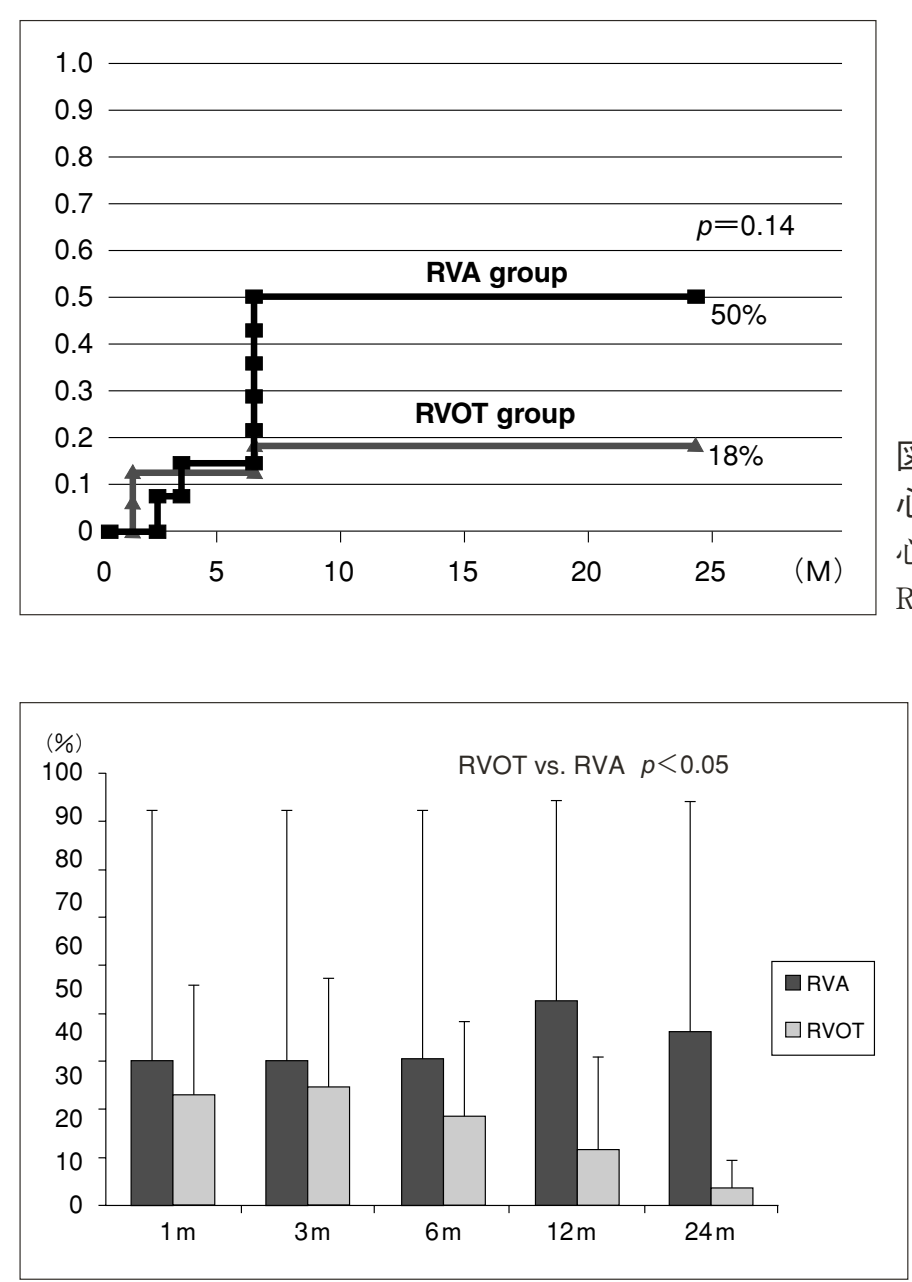

図6

\section{心房細動新規発生率}

心房細動はRVOT群では 16 例中 3 例で発生したのに対し, RVA群では14例中 7例で認めた。
図7

心房細動持続時間

RVOT群とRVA群を比べると，心房細動持続時間はRVOT 群で短かった (平均心房細動持続時間 RVOT 群： $17.8 \%$ vs. RVA 群：37.5\%； p < 0.05).

RVOT : 右室流出路中隔ペーシング群，RVA：右室心尖部 ペーシング群

\section{〔文献〕}

1 ) Andersen HR,Nielsen JC, Thomsen PE, Thuesen L, Mortensen PT, VesterlundT, Pedersen AK : Long-term follow-up of patients from a randomised trial of atrial versus ventricular pacing for sick-sinus syndrome. Lancet, 1997 ; 350 : $1210 \sim 1216$

2 ) Connolly SJ, Kerr CR, Gent M, Roberts RS, Yusuf S, Gillis AM, Sami MH, Talajic M, Tang AS, Klein GJ, Lau C, Newman DM : Effects of physiologic pacing versus ventricular pacing on the risk of stroke and death due to cardiovascular causes. Canadian Trial of Physiologic Pacing Investigators. N Engl J Med, 2000 ; 342 : $1385 \sim 1391$

3 ) Lamas GA, Lee KL, Sweeney MO, Silverman R, Leon A, Yee R, Marinchak RA, Flaker G, Schron E, Orav EJ, Hellkamp AS, Greer S, McAnulty J, Ellenbogen K, Ehlert F, Freedman RA, Estes NA $3^{\text {rd }}$, Greenspon A, Goldman L ; Mode Selection Trial in Sinus-Node Dysfunction : Ventricular pacing or dual-chamber pacing for sinus-node dysfunction. N Engl J Med, 2002 ; 
$346: 1854 \sim 1862$

4 ) Lamas GA, Orav EJ, Stambler BS, Ellenbogen KA, Sgarbossa EB, Huang SK, Marinchak RA, Estes NA $3^{\text {rd }}$, Mitchell GF, Lieberman EH, Mangione CM, Goldman L : Quality of life and clinical outcomes in elderly patients treated with ventricular pacing as compared with dualchamber pacing. Pacemaker Selection in the Elderly Investigators. N Engl J Med, 1998 ; 338 : 1097 1104

5 ) Montanez A, Hennekens CH, Zebede J, Lamas GA : Pacemaker mode selection : the evidence from randomized trials. Pacing Clin Electrophysiol, 2003 ; 26 : $1270 \sim 1282$

6 ) Sweeney MO, Hellkamp AS, Ellenbogen KA, Greenspon AJ, Freedman RA, Lee KL, Lamas GA, for the MOde Selection Trial (MOST) Investigators : Adverse effect of ventricular pacing on heart failure and atrial fibrillation among patients with normal baseline QRS duration in a clinical trial of pacemaker therapy for sinus node dysfunction. Circulation, $2003 ; 107: 2932 \sim 2937$

7 ) Wilkoff BL and the DAVID Trial Investigators : The Dual Chamber and VVI Implantable Defibrillator (DAVID) Trial : rationale, design, results, clinical implications and lessons for future trials. Card Electrophysiol Rev, 2003.7 : 468 472

8 ) Wilkoff BL, Cook JR, Epstein AE, Greene H L, Hallstrom AP, Hsia H, Kutalek, SP, Sharma A ; Dual Chamber and VVI Implantable Defibrillator Trial Investigators : Dual chamber pacing or ventricular backup pacing in patients with an implantable defibrillator : the Dual Chamber and VVI Implantable Defibrillator (DAVID) Trial. JAMA, 2002 ; 288 : 3115 3123

9 ) MADIT II investigators, The clinilal implivations of cummulative right ventricular pacing in the multicenter automatic defibrillator trial II, in J Caridiovasc Electrophysiol, $2005 ; 16: 359 \sim 365$

10) Nielsen JC, Kristensen L, Andersen HR, Mortensen PT, Pedersen OL, Pedersen AK : A randomized comparison of atrial and dual-chamber pacing in 177 consecutive patients with sick sinus syndrome : echocardiographic and clinical outcome. J Am Coll Cardiol, 2003 ; 42 : $614 \sim 623$

11) Tse HF, Yu C, Wong KK, Tsang V, Leung YL, Ho WY, Lau CP : Functional abnormalities in patients with permanent right ventricular pacing : the effect of sites of electrical stimulation. J Am Coll Cardiol, 2002 ; 40 : $1451 \sim 1458$

12) Victor F, Mabo P, Mansour H, Pavin D, Kabalu G, de Place C, Leclercq C, Daubert JC : A randomized comparison of permanent septal versus apical right ventricular pacing : short-term results. J Cardiovasc Electrophysiol, $2006 ; 17: 238 \sim 242$

13) Shukla HH, Hellkamp AS, James EA, Flaker GC, Lee KL, Sweeney MO, Lamas GA ; Mode Selection Trial (MOST) Investigators : Heart failure hospitalization is more common in pacemaker patients with sinus node dysfunction and a prolonged paced QRS duration. Heart Rhythm, $2005 ; 2: 245 \sim 251$ 


\title{
Compartion of the Right Ventricular Outflow Tract Pacing with the Right Ventricular Apex Pacing in the Chronic Phase
}

\author{
Masanori Seino Kazuhiko Tanaka Noritaka Toratani Shiro Nakahara \\ Yoshihiko Sakai Kan Takayanagi
}

Department of Cardiology, Dokkyo Medical University Koshigaya Hospital

\begin{abstract}
Background : Right ventricular apex (RVA) pacing has been thought to be an published effect for the heart function in some studies. Instead, the pacing site of right ventricular outflow tract (RVOT) is known as the alternative pacing site. Previous studies have reported the differences between RVA and RVOT pacing in the early short-term. Therefore the aim of this study is to describe the advantages of RVOT pacing in the chronic phase. Methods : We compared QRS duration, threshold, sense, lead impedance, BNP, left ventricular ejection fraction (EF), left ventricular diastolic/systolic diameter, septal to posterior wall motion delay (SPWMD) and incident rate of atrial fibrillation in the RVA group (20pts) and in the RVOT group (20pts) for two years among patients who don't have cardiac dysfunction (EF $>40 \%)$. Results : The QRS intervals was significantly shorter in the RVOT group than the RVA group (142 \pm 22 vs176 $\pm 18 \mathrm{msec}$. p $<0.001)$, but the QRS duration has not been changed in the RVA group. The threshold ( $0.5 \pm 0.1$ vs $0.7 \pm 0.3 \mathrm{mv} / 0.4 \mathrm{msec})$, sense $(17 \pm 8$ vs $13 \pm 8)$ and impedance $(615 \pm 123$ vs $660 \pm 231)$ were not significantly different. The BNP (70.6 \pm 56 vs $192 \pm 189)$, EF and LV Dd/Ds were not significant different between both groups. SPWMD measurement tended to be better in the RVOT group $(112 \pm 65 \mathrm{Vs} 152 \pm 36)$. Incidence of atrial fibrillation after the pacemaker implantation RVOT grop was less than that of the RVA group (18\% Vs 50\%). The total duration time of the atrial fibrillation in the RVOT group did not increase compared to the RVA group. Conclusion : The RVOT group avoids the risk of disynchronization of the left ventricle, and atrial fibrillation does not worsen. We considered that the RVOT pacing is safe and has more clinical merits compared to the RVA pacing in the chronic phase.
\end{abstract}

Key Words : right ventricular outflow pacing, atrial fibrillation 